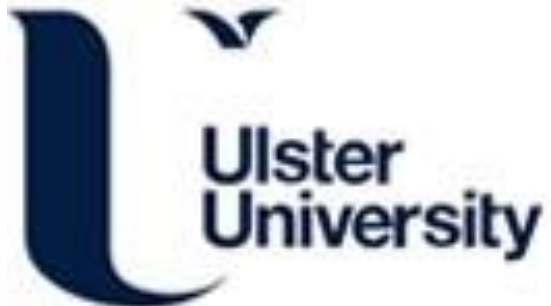

\section{Larval therapy in wound management: a review}

Parnes, A., \& Lagan, K. (2007). Larval therapy in wound management: a review. INTERNATIONAL JOURNAL OF CLINICAL PRACTICE, 61(3), 488-493. https://doi.org/10.1111/j.1742-1241.2006.01238.x

Link to publication record in Ulster University Research Portal

\author{
Published in: \\ INTERNATIONAL JOURNAL OF CLINICAL PRACTICE
}

Publication Status:

Published (in print/issue): 01/03/2007

DOI:

10.1111/j.1742-1241.2006.01238.x

\section{Document Version}

Author Accepted version

\section{General rights}

Copyright for the publications made accessible via Ulster University's Research Portal is retained by the author(s) and / or other copyright owners and it is a condition of accessing these publications that users recognise and abide by the legal requirements associated with these rights.

\section{Take down policy}

The Research Portal is Ulster University's institutional repository that provides access to Ulster's research outputs. Every effort has been made to ensure that content in the Research Portal does not infringe any person's rights, or applicable UK laws. If you discover content in the Research Portal that you believe breaches copyright or violates any law, please contact pure-support@ulster.ac.uk. 


\title{
Larval therapy in wound management: a review
}

\author{
A. Parnés, ${ }^{1}$ K. M. Lagan ${ }^{2}$
}

${ }^{1}$ North \& West Belfast HSST, Podiatry Department, Lancaster Street Clinic, Belfast, N. Ireland, ${ }^{2}$ School of Health Sciences, University of Ulster at Jordanstown, Newtownabbey, Belfast, N. Ireland

Correspondence to: Dr Katie M. Lagan, DPhil., School of Health Sciences,

University of Ulster at Jordanstown, Newtownabbey, Belfast BT37 OQB, N. Ireland Tel.: + 442890366421

Fax: + 442890366028

Email: km.lagan@ulster.ac.uk

\section{Disclosures}

The authors state that they have no interests which may be perceived as posing a conflict or bias.

\section{SUMMARY}

Debridement is an essential component of wound care as the presence of devitalised tissue can impede the healing process. Larval therapy has been used for the debridement of wounds for several hundred years. A plethora of literature is available on larval therapy, but many authors acknowledge the paucity of large-scale clinical trials supporting its effectiveness. While the exact mechanism of larval therapy remains unknown, it encompasses three processes: debridement, disinfection and promotion of healing. This literature review discusses the applications, benefits and disadvantages of larval therapy as well as the processes involved. The literature reviewed suggests that further comprehensive research into the mechanisms involved in larval therapy is required to ensure that it may be used to best medical advantage.

\section{Introduction}

Despite advances in wound care, the increasing incidence of chronic wounds and their numerous socioeconomic consequences have made wound management a key area of focus for health professionals. Several thousand pounds are devoted annually to research in this area (1).

Debridement is an essential component of wound care, as the 'necrotic burden' supported by devitalised tissue impedes the healing process $(2,3)$. In recent years there has been renewed interest into the use of maggots for biosurgical debridement.

Larval therapy (or sometimes known as therapeutic myiasis) is by no means a modern idea, having been used for several hundred years in wound healing by several cultures, including Mayan Indians and Australian aborigines (4). The beneficial effects of therapeutic myiasis were first observed during the Napoleonic war by Larrey, who noted that soldiers whose wounds had become infested with maggots had an improved prognosis. During the First World War, Baer documented the successful treatment of leg ulcers and osteomyelitis using larval therapy, and paved the way for further use of it by doctors of that time. However, the development of antibiotics and improvements in surgical techniques reduced larval therapy to a 'treatment of last resort', reserved for the most intractable wounds (5).

The emergence of antibiotic-resistant strains of bacteria such as methicillin resistant Staphylococcus aureus (MRSA) and the curiosity of researchers has prompted a resurgence of interest in larval therapy (6). As a treatment it meets the demands of clinical governance, being not only beneficial to the patient, but also being proven to be more cost-effective (7). However, application of larval therapy has been stifled by aesthetic considerations.

\section{Applications of larval therapy}

Whilst the effects of therapeutic myiasis were initially recorded in suppurative wounds on the battlefield, numerous case studies have reported its successful use with a variety of wounds. Larval therapy has been employed effectively to treat a wide spectrum of wounds including venous and arterial leg ulcers, osteomyelitis, necrotising fasciitis, traumatic necrotic leg wounds, primary burns, pressure sores and amputation sites including digital amputations in diabetic feet (8). Larval therapy has also been used for the treatment of a variety of intractable wounds, including sacral and leg ulcers of assorted aetiologies (9). Case studies have reported the successful use of larval therapy to treat a wide variety of wounds including chronic diabetic ischaemic foot ulcers (10); necrotic ulceration caused by repetitive footwear trauma of a localised foot metastasis (11); bilateral neuropathic foot ulceration (12) and chronic diabetic foot ulcers (13-15). In all cases, the wounds were successfully debrided of devitalised tissue and granulation tissue developed rapidly. 


\section{General benefits of larval therapy}

Anecdotal evidence has consistently suggested that larval therapy results in a reduction in wound pain and odour, and promotes the healing process with relatively few side effects (16-18). Larval therapy is also reported as being cost-effective in comparison with conventional wound dressings (19). An important study investigated the efficacy and cost-effectiveness of larval therapy vs. hydrogel, and reported that all wounds treated with larval therapy were successfully debrided following one application at a median cost of $\mathfrak{E} 78.64$ (20). Treatment with hydrogel was proven to be less efficient where it was noted that, following 1 month of treatment, one-third of wounds still continued to require treatment. The median cost of treatment for this group was $\mathfrak{E} 136.23$. However, the study involved only 12 patients (six within each group) and thus lacked an adequate number of patients required for large-scale trials to support the efficacy of treatment. The use of larval therapy often resulted in quicker healing, and a subsequent reduction of nursing time and materials (19). Larval therapy has become available on the drug tariff, thus further increasing its costeffectiveness.

A further advantage of larval therapy is that, as larvae are typically applied for 3 days, wounds are disturbed less frequently than conventional dressings that require changing every 1-2 days (21). In addition to this, a further advantage is that treatment can usually be carried out in outpatient and community settings. A study at an outpatient wound clinic on chronic wounds of varying aetiologies reported that using larval therapy resulted in a $62 \%$ decrease in the need for amputation (22).

\section{Larval therapy and multi-resistance}

The use of antibiotics to treat chronic wounds has lead to the emergence of 'resistant' bacteria. Such strains possessed an evolutionary advantage, and were able to increase their population size through Darwinian selection (23). Despite the pharmaceutical response in the form of other antibiotics such as erythromycin and methicillin, further evolution of microbial drug resistance has occurred at a rapid rate, and to a point where antimicrobial resistance has become a major threat to public health (24). The recent development of vancomycin resistance has created an imperative need for alternative methods of treating infection (25). The most predominant microorganisms of concern include Escherichia coli (E. coli), Pseudomonas aeruginosa and MRSA. MRSA has become a frequent cause of nosocomial infections and 'epidemic' strains have consequently become the focus of much media attention in recent years (26).

Larvae offer the benefit of eliminating bacteria from the wound through ingestion and subsequent degradation within their intestinal tract (27). They also act to reduce bacterial activity through the production of inhibitory secretions. Such actions appear to hold true for MRSA as well as other multi-resistant microorganisms, such as Pseudomonas species. While the literature suggests that larval therapy is less effective in wounds infected with E. coli (28), this has since been called into question. In vitro research examining the ingestion by Lucidia sericata larvae of E. coli (which produced a green fluorescent protein) showed a gradual decrease in fluorescence from the anterior section of the larval alimentary canal to its end, thus demonstrating a reduction in the level of bacteria. It may be that a greater quantity of larvae is required in vivo to eradicate wounds of Gram negative bacteria such as E. coli (29).

Other evidence, while anecdotal, supports the use of larval therapy against wound pathogens. In a recent trial, larval therapy was used successfully to treat chronic, MRSA-infected wounds of five patients, including heel ulceration (30). The authors remarked on a few cases where MRSA infection was not successfully eliminated, speculating that the treatment may have been unsuccessful for reasons such as insufficient application of larvae, or that therapy may have been discontinued too early to allow complete eradication of MRSA. Further research reported the successful use of larval therapy in the treatment of three wounds infected with MRSA, however, the author failed to describe the types of wound, their location and their duration (8).

Preliminary research has indicated that the purified secretions of sterile, aseptically raised L. sericata larvae exhibited antibacterial activity against MRSA in vitro; although activity was found to be bacteriostatic rather than bactericidal (28). The authors remarked that the degree of inhibition may have varied as a result of the methods used for the collection of the secretions. Subsequently, it was suggested that the study undervalued the effects of larval secretions, as they are produced continuously in vivo and thus concentrations within the wound would be greater. The authors proposed that a stronger action against the growth of MRSA and other multi-resistant microorganisms could therefore be expected.

A recent study supported this research, finding that secretions from $L$. sericata larvae displayed potent antibacterial action against MRSA (31). It was reported that the most significant antibacterial activity was from a small fraction of larval secretion with 
a molecular weight of $<500 \mathrm{Da}$. However, antibacterial activity was dependent on the selection of an appropriate type of bioassay and optimal conditions. The dilution of larval secretions was believed to have influenced the findings (28).

\section{Disadvantages of larval therapy}

The most commonly mentioned disadvantage of larval therapy is the negative perception with which it is regarded by both patients and practitioners $(5,18,32)$. Although the so-called 'yuk factor' of its clinical appearance (Figure 1) has been frequently reported in case studies, there is little evidence to suggest that patients refuse larval therapy when it is offered (33). The use of 'Biobags' (Polymedics, Belgium), which completely enclose the larvae within a polyvinylalcohol membrane, has become a popular method of improving the application of this treatment (Figure 2). Larvae are able to feed freely through the open cell polymer, but are less visible to the squeamish patient or practitioner (34).

Appropriate education, perhaps incorporated into the continuous professional development of the practitioner, may prove useful in overcoming the scepticism and distaste of practitioners $(8,35)$. Better dissemination of information may also help address the problem of poor survival rates of larvae during treatment because of the lack of moisture (36).

Pain has occasionally been reported by patients suffering from ischaemic wounds $(9,37)$. The cause may be the sharp mouth hooks and spicules with which larvae anchor themselves onto tissue. Contraction of necrotic tissue or $\mathrm{pH}$ changes within a wound may affect pain receptors in proximal healthy tissue (37). Occasionally inflammation of adjacent tissue may also pose problems for adherence of

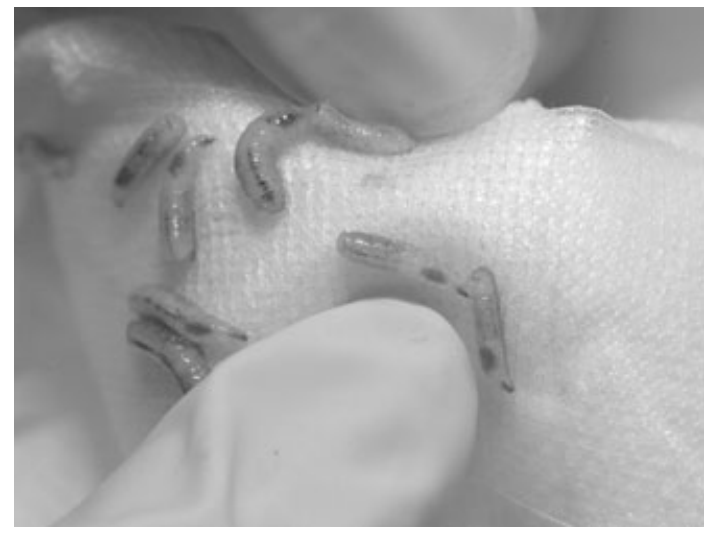

Figure 1 Photograph courtesy of Medical Photography Department, Belfast City Hospitals Trust. Larvae of Lucilia sericata (approximately $15 \mathrm{~mm}$ in length) following removal from wound (post 3 days in contact) dressings, and treatment should be delayed until inflammation has subsided (8). Several authors have proposed that skin surrounding the wound should be protected using hydrocolloids or zinc paste to prevent possible damage from powerful proteolytic enzymes within larval secretions $(33,38,39)$.

A case history has suggested larval therapy to be contraindicated with fistulae, exposed vessels and wounds connecting to vital organs (40). No occurrences of allergic reaction were recorded, but bloodstream infections (with Providencia stuartii and Candida albicans) have been reported where larvae of Protophormia terraenovae and not L. sericata were used (41). Alteration of the disinfection process appeared to eliminate this problem, with no further cases of sepsis occurring during the subsequent 12 months. The risk of cross-infection by escaped larvae may be greatly reduced through careful dressing (42), although no occurrences have been documented (43).

\section{Mechanisms involved in larval therapy}

\section{Wound debridement}

Larvae feed on necrotic tissue, cellular debris and exudate within the wound, thus debriding it of devitalised tissue. In various randomised controlled clinical trials, researchers noted that significantly more wounds healed with frequent debridement, regardless of the use of topical preparations $(44,45)$. Debridement is a critical factor in wound care, and is equally as important as pressure relief in facilitating wound healing (46).

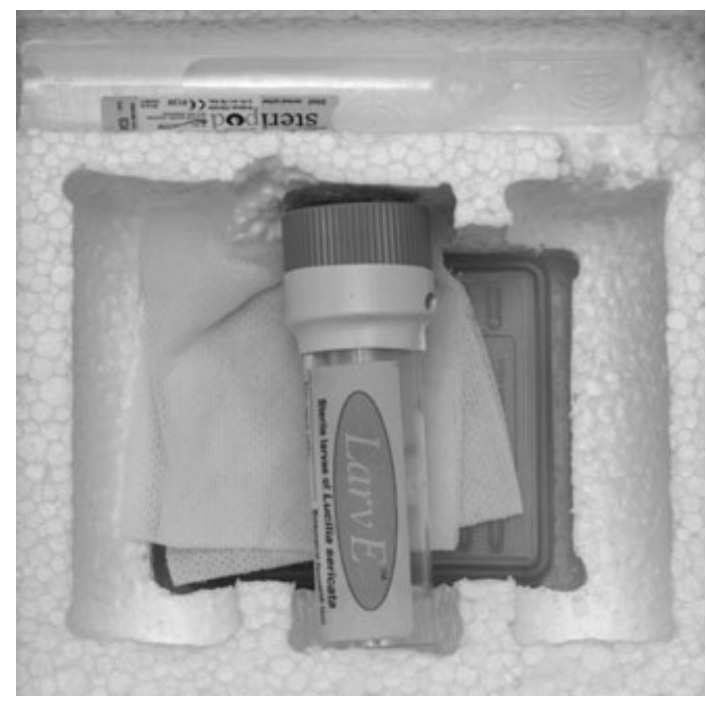

Figure 2 Photograph courtesy of Medical Photography Department, United Hospitals Trust. Sterile LarvE ${ }^{\mathrm{TM}}$ of Lucilia sericata prior to wound application 
The basic mechanism of larval debridement has been described by several researchers (47-49). The digestive juices secreted by larvae during the feeding process have been found to contain a variety of proteolytic enzymes, including trypsin-like and chymotrypsin-like enzymes and collagenase (50). The enzymes selectively debride necrotic tissue, leaving viable tissue unharmed (1). Further research tested the effects of larval secretions of Calliphora erythrocephala on experimental burns on rat skin, and reported that the secretions had proteolytic properties in vitro and in vivo (51).

\section{Wound disinfection}

Chronic wounds are frequently colonised and infected with a variety of wound flora, including Staphylococcus and Streptococcus species, P. aeruginosa and E. coli. Increased bacterial load may impair healing, particularly if a wound becomes infected with antimicrobial resistant bacteria (as discussed above). Disinfection is therefore a critical component of wound healing.

The natural habitats of larvae include corpses and wounds, which typically contain a vast array of pathogenic microorganisms. In response to these conditions larvae are believed to have evolved several effective mechanisms for removing bacteria. During feeding, larvae ingest bacteria within devitalised tissue thus physically removing microorganisms (52). Research has suggested that any bacteria which are not destroyed within the acidic alimentary canal are contained within a tubular structure known as the peritrophic membrane, thus preventing recontamination (53).

Movement of larvae may stimulate the production of serous exudate by the wound, thus increasing irrigation and removing bacteria (1), or wounds may be physically irrigated by larval secretions themselves (54). Other authors believe the process to be more complex, and suggest that larval secretions play a greater role in wound disinfection (55). Early research has shown that larval secretions contain a variety of alkaline components, including ammonium bicarbonate, calcium, allantoin and urea that inhibit bacterial growth (56-58). The subsequent increase in $\mathrm{pH}$ provides an optimum environment for enzymatic activity, and also renders the wound bed uninhabitable to many bacteria, hindering subsequent recolonisation (59).

Disinfection may occur as a result of the release of compounds in larval secretions in conjunction with the digestion of devitalised tissue (60). It has been proposed that larvae release antimicrobial substances as part of an innate response to high levels of bacteria (3). In vitro research isolated a protease resist- ant, thermally stable compound from larval secretions, which exhibited strong antibacterial activity (31). Some antibacterial compounds isolated, such as phenylacetic acid and phenylacetaldehyde, are thought to be released by Proteus mirabilis, a commensal species of bacteria found within the larval alimentary canal (61). The symbiotic relationship between larvae and particular bacterial species appears to facilitate wound disinfection, but further research is required into the mechanism.

\section{Promotion of wound healing}

Research has consisted of small-scale clinical trials and in vitro investigations of the properties of larval secretions. Surprisingly, as it has no benefit to the larvae, therapy appears to encourage the formation of granulation tissue in the wound bed and accelerate wound healing $(9,62)$.

In a comparative study of chronic wounds of multiple aetiologies, it was reported that all wounds healed following 4 weeks of treatment with larval therapy, whereas necrotic tissue was still present on the surface of conventionally treated wounds following 5 weeks (63). This finding was in agreement with earlier work by the author who compared the healing rates of pressure ulcers treated with either conventional dressings or larval therapy (64). Several case studies involving chronic leg ulcers have also recorded the development of granulation tissue within the wound bed $(18,65,66)$. During an in vivo study, a single application of larvae was applied to chronic leg ulcers $(n=30)$ of mixed aetiology (67). The wounds were assessed subjectively, using a wound scoring system, and objectively, using remittance spectroscopy. Following treatment with larvae, remittance was greatly reduced because of an increased quantity of granulation tissue within the wound bed. The authors concluded that larval secretions had a positive effect on wound healing because of the development of granulation tissue and increased tissue oxygenation.

As discussed earlier, the constant movement of larvae within the wound is believed to mechanically stimulate the wound bed (68). However, use of 'Biobags' that inhibit mechanical stimulation has also resulted in improved healing, suggesting that factors other than mechanical stimulation are involved $(34,69)$.

The properties of substances within larval secretions, described as a healing 'active principle' $(56,58)$, have been the subject of subsequent research and suggested that the secretion of allantoin, ammonium bicarbonate and urea provide an optimal growth environment for cells involved in wound healing by acting as growth factors $(70,71)$. The alka- 
line nature of these substances has been reported to have a role in the promotion of healing by altering the $\mathrm{pH}$ of the wound (72).

In vitro research noted that whilst larval secretions stimulated growth of human fibroblast growth, the effect was increased when combined with epidermal growth factor (73). The results indicated that secretions may enhance healing through interaction with compounds released by the wound. This research demonstrated for the first time that the insect moulting hormone, 20-hydroxyecdysone, stimulates fibroblast growth. It was suggested that the resultant tissue proliferation within the wound stimulated by the release of growth factors may provide larvae with better nourishment.

Further research investigated the in vitro effects of larval secretions on human dermal neonatal fibroblast cells and reported that the presence of secretions resulted in a reduction in fibroblast adhesion to fibronectin and collagen (which are constituents of the extracellular matrix modification) (74). The authors suggested that this may be due to proteolytic activity of larval secretions altering the structure of the extracellular matrix. They postulated that this behavioural modification within the wound may promote the formation of new tissue. This supported earlier work proposing that the activity of trypsinlike and chymotrypsin-like proteinases strongly influenced the remodelling of the extracellular matrix (62).

\section{Conclusion}

From the literature reviewed it can be noted that as a treatment, larval therapy offers numerous advantages including rapid wound debridement and elimination of infection, control of pain and odour, and the promotion of wound healing. Use of larval therapy has resulted in few side effects, and has reduced the need for amputation (22). It is also apparent that the treatment also offers an efficient alternative to antibiotic therapy for the treatment of wounds contaminated with a variety of wound pathogens, including MRSA and E. coli. Having been largely superseded by antibiotics, larval therapy has re-emerged as one of the current strategies for targeting microbial resistance.

It is apparent that the literature consists mainly of case studies into the applications of larval therapy. Large-scale clinical trials are required to further examine the efficacy of the process and its effects on healing times. Overall, larval therapy facilitates the efficient and selective debridement of devitalised tissue. The treatment has the added benefit of being bactericidal whilst functioning in harmony with wound processes to promote healing. Whilst not suitable for all wounds, larval therapy should no longer be viewed as a treatment of last resort.

\section{Acknowledgements}

Thanks to Ms J. Cundell, Lecturer/Practitioner, University of Ulster/Belfast City Hospitals Trust, $\mathrm{N}$. Ireland for accessing and providing photographs from Medical Photography departments.

\section{References}

1 Beasley WD, Hirst G. Making a meal of MRSA - the role of biosurgery in hospital-acquired infection. J Hosp Infect 2004; 56: 6-9.

2 Romanelli M, Mastronicola D. The role of wound-bed preparation in managing chronic pressure ulcers. J Wound Care 2002; 11: 30510 .

3 Hoffmann J, Hetru C. Insect defensins: inducible antibacterial peptides. Immunol Today 1992; 13: 411-5.

4 Grossman J. Flies as medical allies. The world \& I 1994; 9: 187-93.

5 Evans H. A treatment of last resort. Nurs Times 1997; 93: 62-5.

6 Sherman RA, Wyle F, Vulpe M. Maggot debridement therapy for treating pressure ulcers in spinal cord injury patients. J Spinal Cord Med 1995; 18: 71-4.

7 Goodman N. Sacred cows to the abattoir! Clinical Governance. BMJ 1998; 317: 1725-7.

8 Courtenay M. The use of larval therapy in wound management in the UK. J Wound Care 1999; 8: 177-9.

9 Mumcuoglu K, Ingber A, Gilead L et al. Maggot therapy for the treatment of intractable wounds. Int J Dermatol 1999; 38: 623-7.

10 Scavée V, Polis FR-X, Schoevaerdts J-Cl. Maggot therapy: many hands make light work. Acta Clin Belg 2003; 103: 405-7.

11 Sealby N. The use of maggot therapy in the treatment of a malignant foot wound. Br J Community Nurs 2004; 9: S16-9.

12 Stoddard SR, Sherman RM, Mason BE et al. Maggot debridement therapy - an alternative treatment for non-healing ulcers. $J \mathrm{Am}$ Podiatr Med Assoc 1995; 85: 218-21.

13 Knowles A, Findlow A, Jackson N. Management of a diabetic foot ulcer using larval therapy. Nurs Stand 2001; 16: 73-6.

14 Semple L. Use of larval therapy to treat a diabetic patient's pressure ulcer. Br J Nurs 2003; 12: S6-13.

15 Richardson M. The benefits of larval therapy in wound care. Nurs Stand 2004; 19: 70-6.

16 Kitching M. Patients' perceptions and experiences of larval therapy. J Wound Care 2004; 13: 25-9.

17 Lau H, Lee F. Maggots in surgery. Ann Coll Surg 1999; 4: 50-3.

18 Green T. Larval therapy in the community - challenge or opportunity? Nurse to Nurse 2004; 4: 51-2.

19 Trudigan J. Evaluating the benefits of larval therapy. Nurs Stand 2002; 16: 65-73.

20 Wayman J, Walker A, Sowinski A et al. Larval debridement therapy: a cost-effective alternative to hydrogel in necrotic venous ulcers: a randomised trial. Br J Surg 2000; 87: 507.

21 MacDougall KM, Rodgers FR. A case study using larval therapy in the community setting. Br J Nurs 2004; 13: 255-60.

22 Sherman RA, Sherman J, Gilead L et al. Maggot debridement therapy in outpatients. Arch Phys Med Rehabil 2001; 82: 1226-9.

23 Kapil A. The challenge of antibiotic resistance: need to contemplate. Indian J Med Res 2005; 121: 83-91.

24 Wise R, Hart T, Cars $\mathrm{O}$ et al. Antimicrobial resistance is a major threat to public health. BMJ 1998; 317: 609-10.

25 Liu C, Chambers HF. Staphylococcus aureus with heterogeneous resistance to vancomycin: epidemiology, clinical significance, and critical assessment of diagnostic methods. Antimicrob Agents Chemother 2003; 47: 3040-5. 
26 Chopra I. Antibiotic resistance in Stahylococcus aureus: concerns, causes and cures. Exper Rev Anti Infect Ther 2003; 1: 45-55.

27 Brocklesby S. MRSA, macrophages and maggots. The Diabetic Foot 2002; 5: 16-24.

28 Thomas S, Andrews A, Hay NP et al. The anti-microbial activity of maggot secretions: results of a preliminary study. J Tissue Viability 1999; 9: 127-32.

29 Steenvoorde P, Jukema GN. The antimicrobial activity of maggots: in vivo results. J Tissue Viability 2004; 14: 97-101.

30 Thomas S, Jones M. Maggots can benefit patients with MRSA. J Pract Nurs 2000; 20: 101-4.

31 Bexfield A, Nigam Y, Thomas S et al. Detection and partial characterisation of two antibacterial factors from the excretions/secretions of the medicinal maggot Lucilia sericata and their activity against methicillin-resistant Staphylococcus aureus (MRSA). Microbes Infect 2004; 6: 1297-304.

32 Sherman RA. Maggot therapy - the last five years. Bull Eur Tissue Repair Soc 2000; 7: 97-8.

33 Evans H. Larvae therapy and venous leg ulcers: reducing the "yuk factor". J Wound Care 2002; 11: 407-8.

34 Grassberger M, Fleischmann W. The biobag - a new device for the application of medicinal maggots. Dermatology 2002; 204: 306.

35 Fear M, Warrell R, Allum L. Introducing the use of sterile maggots into a primary care trust: overcoming barriers. $\mathrm{Br} J$ Community Nurs 2003; 8: S24-30.

36 Rayman A, Stansfield G, Woollard T et al. Use of larvae in the treatment of the diabetic necrotic foot. The Diabetic Foot 1998; 1: $7-13$.

37 Jones M, Thomas S. Larval therapy. Nurs Stand 2000; 14: 47-51.

38 Wolff $\mathrm{H}$, Hansson C. Larval therapy - an effective method of ulcer debridement. Clin Exp Dermatol 2003; 28: 134-7.

39 Johnson S. Larval therapy in the treatment of wounds: case history. Br J Community Nurs 1999; 4: 293-5.

40 Thomas S, Jones M. The use of sterile maggots in wound management. Wound Care Soc Educ Leaflet 1999; 6.

41 Nuesch R, Rahm G, Rudin W et al. Clustering of bloodstream infections during maggot debridement therapy using contaminated larvae of Protophormia terraenovae. Infection 2002; 5: 306-9.

42 Thomas S, Jones M, Shutler S et al. All you need to know about maggots. Nurs Times 1996; 92: 63-76.

43 Wollina U, Karte K, Herold $\mathrm{C}$ et al. Biosurgery in wound healing - the renaissance of maggot therapy. J Eur Acad Dermatol Venereol 2000; 14: 285-9.

44 Steed DL, Donohue D, Webster MW et al. Effect of extensive debridement and treatment on the healing of diabetic foot ulcers. J Am Coll Surg 1996; 183: 61-4.

45 Smith J. Debridement of diabetic foot ulcers. Cochrane Database Syst Rev 2002; 4: CD003556.

46 Armstrong DG, Lavery LA, Vazquez JR et al. How and why to surgically debride neuropathic diabetic foot wounds. J Am Podiatr Med Assoc 2002; 92: 402-4.

47 Thomas S, Jones M, Shutler S et al. Using larvae in modern wound management. J Wound Care 1996; 5: 60-9.

48 Gelbert M. Time's great healers. Nurs Times 1998; 94: 65-9.

49 Ballard K, Baxter H. Developments in wound care for difficult to manage wounds. Br J Nurs 2000; 9: 405-12.

50 Casu RE, Pearson RD, Jarmey JM et al. Excretory/secretory chymotrypsin from Lucilia cuprina: purification, enzymatic specificity and amino acid sequence deduced from mRNA. Insect Mol Biol 1994; 3: 201-11.

51 Vistnes LM, Lee R, Ksander GA. Proteolytic activity of blowfly larvae secretions in experimental burns. Surgery 1981; 90: 83541.

52 Lerch $\mathrm{K}$, Linde HJ, Lehn $\mathrm{N}$ et al. Bacteria ingestion by blowfly larvae: an in vitro study. Dermatology 2003; 207: 362-6.
53 Mumcuoglu K, Miller J, Mumcuoglu M et al. Destruction of bacteria in the digestive tract of the maggot of Lucilia sericata (Diptera: Calliphoridae). J Med Entomol 2001; 38: 161-6.

54 Armstrong DG, Mossel J, Short B et al. Maggot debridement therapy: a primer. J Am Podiatr Med Assoc 2002; 92: 398-401.

55 Fleischmann W, Grassberger M, Sherman R. Maggot Therapy: A Handbook of Maggot-assisted Wound Healing. New York: Thieme, 2004

56 Robinson W. Stimulation of healing in non-healing wounds by allantoin occurring in maggot secretions and of wide biological distribution. J Bone Joint Surg 1935; 17: 267-71.

57 Simmons SW. A bactericidal principle in excretions of surgical maggots which destroys important etiological agents of pyogenic infections. J Bacteriol 1935; 30: 253-67.

58 Livingston SK. The therapeutic active principle of maggots. $J$ Bone Joint Surg 1936; 18: 751-6.

59 Robinson W. Ammonium bicarbonate secreted by surgical maggots stimulates healing in purulent wounds. Am J Surg 1940; 47: 111-5.

60 Sherman RA. Maggot debridement in modern medicine. Infect Med 1998; 15: 651-6.

61 Erdmann GR, Bromel M, Gassner G et al. Antibacterial activity demonstrated by culture filtrates of Proteus mirabilis isolated from larvae of the screwworm (Cochliomyia hominivorax) (Diptera: Calliphoridae). J Med Entomol 1984; 23: 208-11.

62 Chambers L, Woodrow S, Brown AP et al. Cutaneous biology: degradation of extracellular matrix components by defined proteinases from the greenbottle larva Lucilia sericata used for the clinical debridement of non-healing wounds. Br J Dermatol 2003; 148: 14-23.

63 Sherman RA. Maggot therapy for treating diabetic foot ulcers unre sponsive to conventional therapy. Diabetes Care 2003; 26: 446-51.

64 Sherman RA. Maggot versus conservative debridement therapy for the treatment of pressure ulcers. Wound Repair Regen 2002; 10: 208-14.

65 Boon H, Freeman L, Unsworth J. Larvae help debridement. Nurs Times 1996; 92: 76-80.

66 Husain ZS, Fallat LM. Maggot therapy for wound debridement in a traumatic foot-degloving injury: a case report. J Foot Ankle Surg 2003; 42: 371-6.

67 Wollina U, Liebold K, Schmidt WD et al. Biosurgery supports granulation and debridement in chronic wounds - clinical data and remittance spectroscopy. Int J Dermatol 2002; 41: 635-9.

68 Horn KL, Cobb AH Jr, Gates GA. Maggot therapy for subacute mastoiditis. Arch Otolaryngol Head Neck Surg 1976; 102: 377-9.

69 Preuss SF, Stenzel MJ, Esriti A. The successful use of maggots in necrotising fasciitis of the neck - a case report. Head Neck 2004, 26: $747-50$

70 Bengmark S, Rydberg B, Zederfedlt B. Cytotoxic action of quaternary ammonium compounds with special reference to wound healing. Bull Soc Int Chir 1968; 27: 56-63.

71 Pelle MT, Miller OF. Debridement of necrotic eschar with 40\% urea paste speeds healing of residual limbs and avoids further surgery. Arch Dermatol 2001; 137: 1288-90.

72 Rayner K. Larval therapy in wound debridement. Prof Nurse 1999; 14: 329-33.

73 Prete PE. Growth effects of Phaenicia sericata larval extracts on fibroblasts: mechanism for wound healing by maggot therapy. Life Sci 1997; 60: 505-10.

74 Horobin AJ, Shakesheff KM, Woodrow S et al. Cutaneous biology: maggots and wound healing: an investigation of the effects of secretions from Lucillia sericata larvae upon interactions between human dermal fibroblasts and extracellular matrix components. $\mathrm{Br}$ J Dermatol 2003; 148: 923-33.

Paper received July 2006, accepted September 2006 